\title{
Risk Factors of Early Neonatal Deaths in Pediatric Teaching Hospital in Bangui, Central African Republic
}

\author{
Jean Chrysostome Gody ${ }^{1}$, Moyen Engoba ${ }^{3}$, Brice Olivier Bogning Mejiozem ${ }^{1}$, \\ Lydie Verleine Danebera', Evodie Pierrette Kakouguere', Marie Collette Nganda Bangue1, \\ Carine Judith Kiteze Nguinzanemou${ }^{1}$, Romuald Belly de Dieu Komangoya Kpembi ${ }^{1}$, \\ Petula Waraka1, Dusie Lesly Ngoyoli Mbode', Mireille Mande Djapou', \\ Ghislain Franck Houndjahoue ${ }^{1,2}$, George Moyen ${ }^{3}$
}

${ }^{1}$ Centre Hospitalier Universitaire Pédiatrique de Bangui (CHUPB), Bangui, République Centrafricaine

${ }^{2}$ Médecins avec l'Afrique CUAMM International NGO, Padova, Italie

${ }^{3}$ Université Marien Ngouabi, Brazzaville, Congo

Email: *jcgody@hotmail.com

How to cite this paper: Gody, J.C., Engoba, M., Mejiozem, B.O.B., Danebera, L.V., Kakouguere, E.P., Bangue, M.C.N., Nguinzanemou, C.J.K., de Dieu Komangoya Kpembi, R.B., Waraka, P., Mbode, D.L.N., Djapou, M.M., Houndjahoue, G.F. and Moyen, G. (2021) Risk Factors of Early Neonatal Deaths in Pediatric Teaching Hospital in Bangui, Central African Republic. Open Journal of Pediatrics, 11, 840-853.

https://doi.org/10.4236/ojped.2021.114079

Received: November 28, 2021

Accepted: December 27, 2021

Published: December 30, 2021

Copyright $\odot 2021$ by author(s) and Scientific Research Publishing Inc. This work is licensed under the Creative Commons Attribution International License (CC BY 4.0).

http://creativecommons.org/licenses/by/4.0/ (c) (i) Open Access

\begin{abstract}
Background: The neonatal mortality rate in the Central African Republic (CAR) is 42.3 per 1000 live births in 2017, indicating that CAR is with the highest number of newborn deaths. Objective: The objective is to clarify the risk factors of neonatal deaths in this area. Methodology: A case-control study with retrospective data collection. Targets were newborns $>7$ days, hospitalized and dead (cases), and newborns admitted after the respective case during the study period and discharged before the $7^{\text {th }}$ day of life. This study was carried out between 2016 and 2018 in the neonatal unit of the "Complexe Hospitalier Universitaire Pédiatrique de Bangui” (CHUPB), the only national hospital for newborns care in the CAR. Results: We included 902 newborns, with 451 cases of early neonatal death and 451 controls. 4168 newborns were admitted to the neonatology unit with 621 early death cases; a lethality rate of $14.9 \%$. Early neonatal deaths factors were: newborns with low birth weight $(\mathrm{OR}=22.59 ; 95 \% \mathrm{CI}[15.93-32.04] ; \mathrm{P}<0.001)$; mothers who did not attend antenatal care $(\mathrm{OR}=5.54 ; 95 \% \mathrm{CI}[3.95-7.79] ; \mathrm{P}<0.001)$, home delivery $(\mathrm{OR}=0.70 ; 95 \% \mathrm{CI}[0.03-0.15] ; \mathrm{P}<0.001)$; young maternal age $<25$ years $(\mathrm{OR}=2.08 ; 95 \% \mathrm{CI}[1.58-2.73] ; \mathrm{P}<0.001)$; non-medical transport $(\mathrm{OR}=$ 2.14; 95\% CI [1.03 - 4.46]; $\mathrm{P}=0.03)$; origin from remote areas $(\mathrm{OR}=5.25$; 95\% CI [3.95 - 6.98]; $\mathrm{P}<0.001)$; isolated prematurity $(\mathrm{P}<0.01)$; anoxo-ischemic encephalopathy ( $\mathrm{OR}=12.72 ; 95 \% \mathrm{CI}[6.54-34.73]$; $\mathrm{P}<0.01)$; delivery by cesarean section $(\mathrm{OR}=0.59 ; 95 \% \mathrm{CI}[0.41-0.84]$; $\mathrm{P}<0.001)$; pre-
\end{abstract}


term delivery $(\mathrm{OR}=29.36 ; 95 \% \mathrm{CI}[20.12-42.81]$; $\mathrm{P}<0.001)$, and maternal lower education $(\mathrm{OR}=5.65 ; 95 \% \mathrm{CI}[4.08-7.81]$; $\mathrm{P}<0.001)$. Conclusion: The early neonatal mortality rate remains high in this area. Controlling the factors mentioned above might lead to improving the survival of newborns.

\section{Keywords}

Early Neonatal Mortality, Risk Factors, CHUPB, CAR

\section{Introduction}

Neonatal death, including children born alive and dead between birth and the 28 th day of life, is a public health concern. It is considered early death when it occurs before the first week of life [1]. It can be divided into two sub-categories: early neonatal mortality between 0 and 6 days and late neonatal mortality between 7 and 27 days [2].

According to the World Health Organization (WHO), overall neonatal deaths are 2.6 million [3]. This neonatal mortality is an indicator of obstetric and neonatal care quality which is the witness of the socio-economic development level of a country. This mortality remains 10 to 15 times higher in developing countries than in developed ones [4]. Thus, only one in 1000 dies in the first 28 days of life in Japan but, in CAR, out of 1000 babies born, 42.3 will not survive at one month of life, otherwise one in 20 newborns. This epidemiological profile data makes CAR the first in the world among low-income countries with the highest number of neonatal deaths [5]. Likewise, intra-hospital neonatal mortality is higher and varies according to the health setting. Early neonatal mortality can exceed $50 \%$ in the neonatal units in low-income countries' hospitals [6] [7]; the contributing factors are the socio-economic environment, access to care, the type of patients, the medical equipment, and human resources [7].

In sub-Saharan Africa, where the Central African Republic is located, the birth of a baby is an important and joyful social event for the family and the whole community. However, the death of a newborn is a trauma to the family for which the community often tries to find fatalistic explanations. Few data on early neonatal death in CAR are available; hence this case-control study aims to determine the frequency, clinical, and outcome characteristics and to identify the risk factors associated with early neonatal mortality at the pediatric teaching hospital of Bangui.

\section{Methodology}

The study was retrospective. It was carried out between 2016 and 2018 in the neonatal unit of the pediatric teaching hospital of Bangui, the only national hospital for newborn care in the CAR. No conventional care system and graduated patient management are operational in the current health pyramid. Barely $4 \%$ of 
patients are referred from peripheral health facilities to the pediatric hospital.

The unit includes in situ diagnostic tools (pulse oximeter, transcutaneous bilirubinometer, glucometer, and urine strips), warming (radiant lamps), manual ventilation, oxygen therapy (oxygen concentrator, masks, and nasal cannula) as well, as for intravenous and umbilical infusions. Cardiorespiratory monitors, phototherapy devices, and syringe pumps are also available. Assisted ventilation and positive airways pressure at the end of expiration are not available. The skin-to-skin or kangaroo method sub-unit has 8 beds with breastfeeding support. The hospital laboratory operates 24 hours 7 days and performs biological hematologic, biochemical investigations (dosage of C-reactive protein, serum creatinine, bilirubin, and blood ionogram) and bacteriology (blood cultures, urine cultures, etc. analyzes of cerebrospinal fluid). The imaging department can perform standard radiology and ultrasound. Computed tomography is feasible in the imaging unit close to the hospital but is not free of charge. The staff members of the neonatal unit include a pediatric neonatologist, residents in pediatrics, two nursery nurses, and ten nurses. The ratio is equal to one nurse for 4.2 newborns.

The retrospective data collection included as cases: any newborn less than seven days hospitalized in the ward and died during the study period. The control group consisted of all newborns admitted to the ward immediately after their respective cases during the study period and who survived till their seventh day of life. Those who died upon arrival or after seven days of life, as well as those released alive after seven days of life, were not included. The study variables related to the mother were age, parity, quality of antenatal care, occupation, socio-economic level, education level, location, marital status, and Clinical incidents during the current gestation. Newborn variables were origin, mean of transport, reason for hospitalization, type of delivery, gestational age, sex, birth weight, hospitalization duration, clinical signs, diagnosis, treatment and outcome.

A low level of education was defined by education not exceeding elementary level or lack of education. The housewife is defined as any woman whose main occupation is to take care of the household tasks. Low birth weight is defined as a birth weight less than 2500 grams. Respiratory distress is defined as a Silverman score $\geq 4$. The model of appropriate antenatal care (ANC) used for this study is that of WHO 2016, with eight ANC [8]. Data was collected from the service's registers and medical records. These collected data have been kept secret for the respect of confidentiality. The data had been analyzed using Epi Info 7 software in version 7.1.3.3. The p-value $<0.05$ was considered significant, and the odds ratio was calculated with a $95 \%$ confidence interval.

\section{Results}

Out of 4168 newborns admitted to the neonatal department of the pediatric hospital, early death occurred in 621 ; a lethality of $14.90 \%$. From one year to anoth- 
er, we observed a lethality rate of $14.41 \%(195 / 1353)$ in $2016,17.12 \%(245 / 1431)$ in 2017 , and $13.07 \%(181 / 1384)$ in 2018 , as shown in Figure 1.

Among the 621 files of newborns that died early, we kept 451 files whose information could be used in accordance with the case inclusion criteria.

Likewise, out of the 2245 files of newborns survived before the $7^{\text {th }}$ day, we selected 451 files whose information could be used in accordance with the case control criteria. One control was matched to each case.

\subsection{Maternal Characteristics and Early Neonatal Death}

The mean age of the mothers in the cases group was $22 \pm 6$ years versus $26 \pm 5$ years for the control group's mothers $(P<0.001)$. Teenager and young mothers (under 25 year-old) represented $60.53 \%(n=546)$, with the percentage of $57.14 \%$ $(\mathrm{n}=312)$ and $42.86 \%(\mathrm{n}=234)$, respectively among cases and controls. They lived in rural areas in $68.25 \%(n=329)$ for the cases and $31.75 \%(n=153)$ for the controls $(p<0.001)$ and were primiparous in $50.16 \%(n=311)$ for the cases versus $49.83 \%(n=309)$ for the controls. Among the cases, mothers have no education in $62.14 \%(n=384)$ versus $37.86 \%$ for controls $(n=234)$. Newborns of women who did not attend antenatal care were 5 times more likely to die early $(\mathrm{OR}=5.5495 \% \mathrm{CI}[3.95$ - 7.79]; $\mathrm{P}<0.001)$. About one in seven women (58.10\%) with Clinical incidents during the current gestation had the risk of losing her baby early $(\mathrm{OR}=1.4 ; 95 \% \mathrm{CI}[1.04-2.10] ; \mathrm{P}=0.02)$. Childbirth in a hospital was a protective factor against death $(\mathrm{OR}=0.70 ; 95 \% \mathrm{CI}[0.03-0.15]$; $\mathrm{P}$ $<0.001)$. Cesarean delivery was counted among the risk factors for early neonatal death $(\mathrm{OR}=0.59 ; 95 \% \mathrm{CI}[0.41-0.84] ; \mathrm{P}<0.001)$. Finally, newborns of women with lower education, were 5.65 time more likely to die (OR $=5.65 ; 95 \%$ CI [4.08 - 7.81]; P $<0.001)$. See Table 1.

\subsection{Characteristics of the Newborn and Early Neonatal Death}

Male sex was $48.27 \%(\mathrm{n}=307)$ among cases and $51.73 \%(\mathrm{n}=329)$ among controls. The sex ratio was 2.13 for cases and 2.69 for controls.

Newborns with low birth weight were 22.59 times more at risk of early neonatal death $(\mathrm{OR}=22.59 ; 95 \% \mathrm{CI}[15.93$ - 32.04]; $\mathrm{P}<0.001)$. The risk of early neonatal death was 29.36 times greater in newborns of gestational age below 37 weeks of amenorrhea based on Finnstrom score (OR $=29.36$; 95\% CI [20.12 42.81]; $\mathrm{P}<0.001)$. Non-medical transport increased the risk of early neonatal

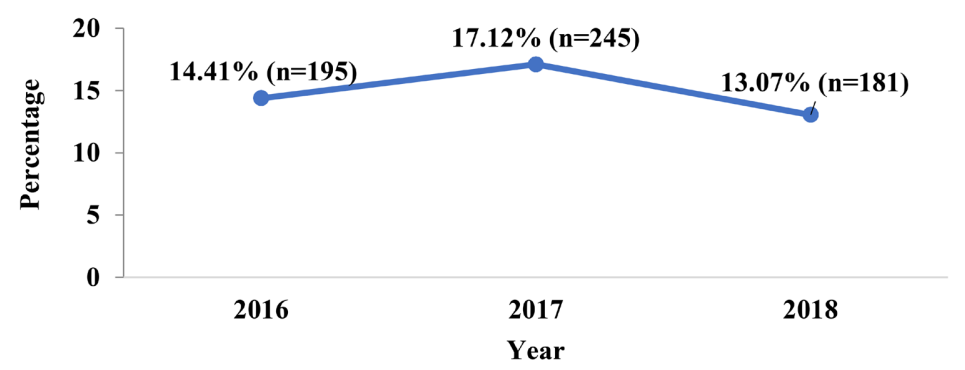

Figure 1. Distribution of early neonatal death by year. 
Table 1. Relationship between early neonatal death and the characteristics of the mother.

\begin{tabular}{|c|c|c|c|c|}
\hline Parameter & $\begin{array}{c}\text { Death cases } \\
(\mathrm{N}, \%)\end{array}$ & $\begin{array}{c}\text { Cases controls } \\
(\mathrm{N}, \%)\end{array}$ & OR & $\mathbf{P}$ \\
\hline \multicolumn{5}{|l|}{ Mothers age (in year) } \\
\hline$<25(\mathrm{n}=546)$ & $312(57.14)$ & $234(42.86)$ & \multirow{2}{*}{$2.08[1.58-2.73]$} & \multirow{2}{*}{$<0.01$} \\
\hline$\geq 25(\mathrm{n}=356)$ & $139(39.05)$ & $217(60.95)$ & & \\
\hline \multicolumn{5}{|l|}{ Location } \\
\hline $\operatorname{Rural}(\mathrm{n}=482)$ & $329(68.25)$ & $153(31.75)$ & \multirow{2}{*}{$5.25[3.95-6.98]$} & \multirow{2}{*}{$<0.01$} \\
\hline Urban $(\mathrm{n}=420)$ & $122(29.1)$ & $298(70.9)$ & & \\
\hline \multicolumn{5}{|l|}{ Marital status } \\
\hline Singles $(n=521)$ & $250(47.98)$ & $271(52.02)$ & \multirow{2}{*}{$0.82[0.63-1.07]$} & \multirow{2}{*}{0.07} \\
\hline Maried $(\mathrm{n}=381)$ & $201(52.75)$ & $180(47.25)$ & & \\
\hline \multicolumn{5}{|l|}{ Education level } \\
\hline No education $(\mathrm{n}=618)$ & $384(62.14)$ & $234(37.86)$ & \multirow{2}{*}{$5.65[4.08-7.81]$} & \multirow{2}{*}{$<0.01$} \\
\hline Educateds $(\mathrm{n}=280)$ & $63(22.50)$ & $217(77.50)$ & & \\
\hline \multicolumn{5}{|l|}{ Profession } \\
\hline Paid employment $(\mathrm{n}=72)$ & $33(45.83)$ & $39(54.17)$ & \multirow{2}{*}{$0.83[0.5-1.35]$} & \multirow{2}{*}{0.23} \\
\hline Other Jobs $(\mathrm{n}=830)$ & $418(50.36)$ & $412(49.64)$ & & \\
\hline \multicolumn{5}{|l|}{ Parity } \\
\hline Primiparous $(n=620)$ & $311(50.16)$ & $309(49.84)$ & \multirow{2}{*}{$1.02[0.77-1.35]$} & \multirow{2}{*}{0.88} \\
\hline Multiparous $(\mathrm{n}=282)$ & $140(49.64)$ & $142(50.36)$ & & \\
\hline \multicolumn{5}{|l|}{ Antenal care well followed } \\
\hline No $(n=248)$ & $194(78.22)$ & $54(21.78)$ & \multirow{2}{*}{$5.54[3.95-7.79]$} & \multirow{2}{*}{$<0.01$} \\
\hline Yes $(\mathrm{n}=654)$ & $257(39.29)$ & $397(60.71)$ & & \\
\hline \multicolumn{5}{|l|}{ Delivery place } \\
\hline Hospital $(\mathrm{n}=805)$ & $362(44.96)$ & $443(55.04)$ & \multirow{2}{*}{$0.70[0.03-0.15]$} & \multirow{2}{*}{$<0.01$} \\
\hline Home $(\mathrm{n}=97)$ & $89(91.75)$ & $8(8.25)$ & & \\
\hline \multicolumn{5}{|l|}{ Type of delivery } \\
\hline Vaginal $(\mathrm{n}=747)$ & $357(47.79)$ & $390(52.21)$ & \multirow{2}{*}{$0.59[0.41-0.84]$} & \multirow{2}{*}{$<0.01$} \\
\hline Ceasarian section $(n=155)$ & $94(60.64)$ & $61(39.36)$ & & \\
\hline
\end{tabular}

Clinical incidents during the current gestation

\begin{tabular}{lllll} 
Yes $(\mathrm{n}=155)$ & $90(58.10)$ & $65(41.90)$ & & \\
No $(\mathrm{n}=747)$ & $361(48.33)$ & $386(51.67)$ & & \\
\hline
\end{tabular}

death by $2.14(\mathrm{OR}=2.14 ; 95 \% \mathrm{CI}[1.03-4.46] ; \mathrm{P}=0.03)$. The risk of early neonatal death was 12.72 times in anoxic ischemic encephalopathy $(\mathrm{OR}=12.72$; 95\% CI [6.54 - 24.73]; P < 0.001). Congenital malformations increased the risk of 
early neonatal death by 1.2 , but the link was not statistically significant $(\mathrm{OR}=$ 1.2; 95\% CI [0.36 - 3.96]; $\mathrm{P}=0.09$ ). See Table 2 .

Table 2. Relationship between early neonatal death and newborn characteristics.

\begin{tabular}{|c|c|c|c|c|}
\hline Parameters & $\begin{array}{c}\text { Death cases } \\
\mathrm{N}(\%)\end{array}$ & $\begin{array}{c}\text { Case control } \\
\mathrm{N}(\%)\end{array}$ & OR & $\mathbf{P}$ \\
\hline \multicolumn{5}{|l|}{ Sex } \\
\hline Male $(n=636)$ & $307(48.27)$ & $329(51.73)$ & \multirow{2}{*}{$0.79[0.5-1.05]$} & \multirow[b]{2}{*}{0.10} \\
\hline Female $(n=266)$ & $144(54.14)$ & $122(45.86)$ & & \\
\hline \multicolumn{5}{|c|}{ Gestationnal age (in week) } \\
\hline$<37(\mathrm{n}=390)$ & $345(88.46)$ & $45(11.54)$ & \multirow{2}{*}{$29.36[20.12-42.81]$} & \\
\hline$\geq 37(\mathrm{n}=512)$ & $106(20.70)$ & $406(79.30)$ & & \\
\hline
\end{tabular}

\section{Weight (in grams)}

$$
\begin{aligned}
& <2500(\mathrm{n}=487) \\
& \geq 2500(\mathrm{n}=415)
\end{aligned}
$$

$$
\begin{array}{ll}
389(79.87) & 98(20.13) \\
62(14.94) & 353(85.06)
\end{array}
$$

\section{Transportation means}

$$
\begin{aligned}
& \text { Non médicalisé }(\mathrm{n}=868) \\
& \text { Médicalisé }(\mathrm{n}=34)
\end{aligned}
$$$$
440(50.7) \quad 428(49.3)
$$$$
11(32.35)
$$$$
23 \text { (67.65) }
$$

\section{Diagnosis at time of death}

\section{Prematurity with complication}

$$
\begin{array}{lcc}
\text { Yes }(\mathrm{n}=184) & 150(81.53) & 34(18.47) \\
\text { No }(\mathrm{n}=718) & 301(41.9) & 417(58.1)
\end{array}
$$

\section{Prematurity without complication}

$$
\begin{aligned}
& \text { Yes }(\mathrm{n}=142) \\
& \text { No }(\mathrm{n}=760)
\end{aligned}
$$

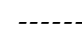
$<0.01$

\section{Neonatal distress respiratory}

$$
\begin{array}{lcc}
\text { Yes }(\mathrm{n}=191) & 103(53.92) & 88(46.08) \\
\text { No }(\mathrm{n}=711) & 348(48.9) & 363(51.1)
\end{array}
$$

$103(53.92) \quad 88(46.08)$

Encephalopathy anoxo-ischémia

$$
\begin{aligned}
& \text { Yes }(\mathrm{n}=111) \\
& \text { No }(\mathrm{n}=791)
\end{aligned}
$$

\section{Neonatal infection}

$$
\begin{aligned}
& \text { Yes }(\mathrm{n}=253) \\
& \text { No }(\mathrm{n}=649)
\end{aligned}
$$$$
85(33.59)
$$$$
366(33.6)
$$$$
168(66.40)
$$$$
283(66.4)
$$

\section{Congenital malformation}

$$
\begin{aligned}
& \text { Yes }(\mathrm{n}=11) \\
& \text { No }(\mathrm{n}=891)
\end{aligned}
$$$$
6(54.54) \quad 5(45.46)
$$$$
445 \text { (49.9) } \quad 446(50.1)
$$

$0.39[15.93-32.04]<0.01$

$12.72[6.54-24.73]<0.01$

$$
1.2[0.36-3.96] \quad 0.09
$$


Continued

\begin{tabular}{|c|c|c|c|c|}
\hline \multicolumn{5}{|c|}{ Jaundice encephalopathy } \\
\hline Yes $(n=3)$ & $2(66.6)$ & $1(33.4)$ & \multirow{2}{*}{$2[0.18-22.18]$} & \multirow{2}{*}{0.56} \\
\hline No $(n=899)$ & 449 (49.9) & $450(50.1)$ & & \\
\hline \multicolumn{5}{|c|}{ Neonatal Tetanus } \\
\hline Yes $(n=3)$ & $2(66.6)$ & $1(33.4)$ & \multirow{2}{*}{$2[0.18-22.18]$} & \multirow{2}{*}{0.56} \\
\hline No $(n=899)$ & $449(49.9)$ & $450(50.1)$ & & \\
\hline \multicolumn{5}{|c|}{ Hemorrhagic disease of newborns } \\
\hline Yes $(n=2)$ & $2(100)$ & $0(00)$ & & \multirow{2}{*}{0.15} \\
\hline No $(n=900)$ & $449(49.88)$ & $451(50.2)$ & & \\
\hline
\end{tabular}

\section{Discussion}

The present study focused on newborns managed in a neonatal unit of the only national referral hospital center, which receives approximately $95 \%$ of births with problems in Bangui and its surroundings. These newborns already have a higher risk of mortality compared to healthy newborns. Thus, the results obtained remain valid for the framework of the study and do not reflect the situation in the general population where the neonatal mortality rate is 42.3 deaths per 1000 live births [3]. Under the conditions of hospital care in Bangui, Bobossi in 1999 reported the result of a pediatric intervention in the delivery room for newborns requiring intensive care. The hospital mortality rate was 9.7\% [9]. In 2003, the latter observed this time, at the Pediatric hospital—the only pediatric unit in the Central African Republic geographically separated from maternity hospitals-overall intra-hospital mortality of around $28.4 \%$ [10]. By applying the $2 / 3$ rule according to Lawn [11], we would have an early intra-hospital mortality rate of about $18.9 \%$ in 2003 , close to the trend observed in 2017. These comparisons show a fluctuation in the rate of early intra-hospital mortality from $13.07 \%$ to $18.9 \%$, clearly superior to the results obtained in the first hours after resuscitation in the maternity ward of the Bangui Community Hospital in 1999 (9.7\%).

It was a pilot project that was never carried out. According to this analysis, it is more than urgent to reduce external transfer by creating neonatal units in the referral maternities in Bangui; waiting for decentralization in the different health regions of the country. The low mortality in facilities caring for mother and newborn is a reality confirmed by the observations of Kedy in Douala with 6.6\% [12], Garba in Niamey with 6.31\% [13], Manzar in Pakistan with 6.39\% [14], and Baker in New York with 1.9 per 1000; materializing both the protective aspect of in situ interventions for the newborn and the quality of care in developed countries [15]. The difference in care observed, between developed and developing countries, for hospitals with neonatal intensive care units as well as in health systems where referral to tertiary care is possible, reveals the lack of interventions upstream of maternity hospitals and pediatric units to prevent obstetric 
complications [16] [17] [18].

For the Central African Republic, during the study period, the lack of antenatal and pre-natal interventions would be partly induced by armed conflicts. Indeed, in addition to the conflicts responsible for the decline in the use of services, the weak contribution of the State to health expenditure previously prevented the development of the health system in a context where the population-mostly poor-struggled to access care [19]. Thus, with free care, already effective in the pediatric unit, it is necessary to combine the optimization of pregnancy monitoring and the organization of timely transfers of parturients to obstetric referral centers to reduce the cause of the obstetric complications of neonatal deaths [20] [21]; waiting for the end of armed conflicts and the increase in the financial contribution of the State to health care.

\subsection{About the Relationship between Early Neonatal Death and Maternal Characteristics}

For maternal factors, our results showed that parturients under 25-year-old, primiparous, and not attending school are the most affected by early neonatal deaths. This observation was made by Blondel in France [22] and could be explained, among others, by the fact that in CAR, sexual activities are precocious, in particular with unwanted pregnancies: a source of inappropriate follow-up; negatively impacting the quality of antenatal and post-natal. The data from our work supported observations on the barriers to accessing pregnancy follow-up [23]. Thus, the lack of prenatal consultation, multiplying by 5.54 the risk of death of the newborn, is usual [7] [24] [25] [26] [27]. For Garba in Niger, mothers who have had a good ANC are 3.72 times less likely to see their child die [13]. Like poor pregnancy follow-up, rural origin increases the risk of early neonatal death. This has been reported in several studies suggesting the geographic barrier and/or life in rural areas as risk factors for neonatal death [25] [28] [29].

Contrary to the majority of studies that consider the cesarean section as a protective factor of early neonatal death and would even make it possible to avoid perinatal mortality by $71 \%$ [30], in our study; this mode of delivery is linked to the risk of early neonatal death. This observation, which corroborates Akinyemi's observations [21], would be because cesarean sections are often indicated in our maternity hospitals for maternal rescue or acute fetal suffering; exposing them to the risk of induced prematurity and neonatal asphyxia; so many clinical situations unfavorable to the survival of the newborn.

\subsection{About the Relationship between the Early Neonatal Death and Newborn Characteristics}

In our study, most newborns are male, of low birth weight, and for most of the time, born before 37 weeks of gestation in respiratory distress and transported to the pediatric unit by non-medical transportation. This male predominance does not influence the occurrence of early neonatal deaths, unlike observations showing the male sex as a risk factor for neonatal mortality [31] [32] [33] [34] [35]. The 
factors that cause early neonatal mortality are preterm delivery, low birth weight, and inappropriate transport. Neonatal infection, anoxo-ischemic encephalopathy (EAI), and congenital malformations are the most observed neonatal pathologies.

In our series, the first day of life is the deadliest of the neonatal period with a proportion of $85.15 \%(n=367)$; obeying the two-thirds rule of deaths occurring within 24 hours of birth, reported by several authors [10] [11] [36]. Considering the risk factors of early lethality, prematurity, being the primary goal of antenatal consultations, has been shown to be the first direct cause of early neonatal mortality. This does not seem surprising, taking into account many factorsproviders of prematurity and its consequences-present in the Central African Republic and described elsewhere linked to the low socio-economic level, insufficient medical follow-up of pregnancy, early motherhood, childbearing, long journeys, and inappropriate means of transport [37] [38] [39]. But this predominance of prematurity is not particular to developing countries [40] [41]. Regarding selection bias for prematurity and hypotrophic infants, there are often difficulties in estimating gestational age (ignorance of the date of the last menstruation, absence of early ultrasound) [42]. But, a careful clinical examination (Finnstrom score) allowed us most often to differentiate between the true premature and the hypotrophic newborn. Anyway, newborns with low birth weight have 22.59 times more risk of dying than those with normal birth weight. Several authors in Africa [24] [25] [43] [44] [45] [46] [47] and in Asia [48] [49] have reported the same findings. The main thing is to observe that most children with low birth weight are not preterm-that they have in common problems of growth in utero, generally due to the poor health of their mother [50] in order to intervene upstream on the health problems of women of childbearing age.

Regarding the pathologies found in early deaths newborns in our series, malformations are major contributors, followed by anoxo-ischemic encephalopathy, infections, and respiratory distress. Infections, prematurity, and brain injury are frequently cited causes of neonatal mortality in Africa, varying in their proportion from one site to another [51] [52]. According to Lawn [53], worldwide in 2012, the clinical situations frequently associated with neonatal mortality are complications of prematurity (0.99 million, 34\%), perinatal asphyxia (0.72 million, 25\%), and infections (including sepsis, meningitis, and pneumonia; 0.64 million, 22\%). It is also reported in Lawn's systematic review that complications of preterm delivery have similar proportions in countries with low mortality and high mortality. However, poor management of preterm newborns is observed in most countries with high mortality. Yenan [54] pointed out the limits of human and material resources in newborn care management in Bouaké. Azaria [40] underlines that "in addition to the organization of societies around access to care and the influence of modes of solidarity on the national health of people in precarious situations, also include ethnic differences or geographical, educational level and territorial inequalities" and proposes to take into account while analyzing. Thus, we have to recognize that national solidarity, through free health 
care offered to children in the Central African Republic, is far from solving the problems of neonatal morbidity and mortality. It seems like this system generates the inadequacy between need and offer as human and material resources are lacking, given the realities revealed by Yenan et al. [54]. If we refer to the study on the nurse's workload carried out in 2002 by Aitken, the patient/nurse ratio is not blamed [55]. The workload of the pediatrician likely remains to be blamed at the pediatric hospital. Indeed, the standards of practice in the neonatal hospitalization unit require the presence of a pediatrician 24 hours 7 days skilled in neonatal resuscitation [56]; whereas in our case, the pediatrician-with this skill-provides care in the unit for 8 hours out of the 24 required.

Our observation concerning the strong implication of congenital malformations is supported by the assertions that a gradient between the risks of congenital anomaly increase as the precariousness index increases [57].

\section{Conclusions}

This study, limited to the only referral neonatal unit in the Central African Republic, showed determinants of early neonatal mortality often observed in countries with high mortality is related to the young age of the mother, the poor antenatal care, rural area, cesarean section, gestational age $<37$ weeks, weight $<$ $2500 \mathrm{~g}$, external transfer, infections, perinatal asphyxia, congenital abnormalities, and respiratory distress.

The literature review has shown us that beyond national solidarity targeting the most vulnerable in the form of free healthcare implementation at the neonatal unit in Bangui, it would be necessary to decentralize the care of pregnant women and newborns, facilitate access to education for mothers and improve the offer/need ratio in response strategies aiming to increase newborn survival in the Central African Republic.

\section{Conflicts of Interest}

The authors declare no conflicts of interest regarding the publication of this paper.

\section{References}

[1] OMS (2011) La mortalité néonatale baisse trop lentement, surtout en Afrique. 12 p.

[2] Amorissani-Folquet, M., Dainguy, E., Kouakou, C., Benie, B.V.J. and Houenou, Y. (2007) Facteurs de risque de mortalité néonatale précoce du nouveau-né à terme au service de pédiatrie du chu de cocody. Revue International des Sciences Médicales, 9, 28-33.

[3] Lawn, J.E., Blencowe, H., Waiswa, P., et al. (2016) For the Lancet Ending Preventable Stillbirths Series Study Group with the Lancet Stillbirth Epidemiology Investigator Group. Stillbirths: Rates, Risk Factors, and Acceleration towards 2030. Lancet.

[4] Hoan, P.T., Bao, T.V., Huong, N.T., Manirankunda, L. and Boelaert, M. (2000) Mortalité Néonatale précoce à l'Hôpital de gynécologie-obstétrique de Hanoï, Vietnam. Bulletin de la Société de Pathologie Exotique, 93, 62-65. 
[5] Taylor, G., Devine, S., Carvajal-Aguirre, L., Hug, L., Porth, T., You, D.Z., Arts, M., Begin, F., Chaiban, T., Chandy, L., Hayashi, C., Hereward, M., Mehra, V., Mshvidobadze, A., Pearson, L., Peterson, S., Rogers, K., Sharrow, D., Taqi, I., Zaka, N. and Zeck, W. (2018) Pour chaque enfant, une chance de vivre. L'urgence de mettre fin à la mortalité néonatale. UNICEF, Palais des Nations, $44 \mathrm{p}$.

[6] Balaka, B., Agbere, A.D., Kpemissi, E., et al. (1998) Évolution de la mortalité néonatale précoce en dix ans (1981-1982et1991-1992) au CHU de Lomé: Quelle politique de santé néonatale pour demain ? Médecine d’ Afrique Noire, 45, 430-434.

[7] Kedy Koum, D.C., Essomba, N.E., Ngaba, G.P., Sintat, S., Koki Ndombo, P. and Coppieters, Y. (2015) Morbidité et facteurs de risque de mortalité néonatale dans un hôpital de référence de Douala. Pan African Medical Journal, 20, Article No. 258.

[8] OMS (2018) Recommandations de l'OMS concernant les soins prénatals pour que la grossesse soit une expérience positive

https://apps.who.int/iris/bitstream/handle/10665/259584/9789242549911-fre.pdf;se quence $=1$

[9] Bobossi Serengbe, G., Serdouma, E., Gody, J.C., Habarugira, R. and Gresenguet, G. (2002) La réanimation néonatale en milieu pédiatrique à l'hôpital communautaire de Bangui. Revue Internationale des Sciences Médicales, 4, 89-95.

[10] Bobossi, S.G., Deyamissi-Sana, T.S., Diemerh, C. and Gauduelle, A.G. (1994) Mortalité Néonatale en République centrafricaine. Médecine d Afrique Noire, 51, 159-163.

[11] Lawn, J.E., McCarthy, B. and Ross, S.R. (2001) The Healthy Newborn: A Reference Manual for Program Managers. CDC et CARE, Atlanta.

[12] Kedy Koum, D., Exhenry, C., Penda, C.I., Nzima Nzima, V. and Pfister, R.E. (2014) Morbidité et mortalité néonatale dans un hopital de district urbain à ressources limitées à Douala, Cameroun. Archives de Pediatrie, 21, 147-156. https://doi.org/10.1016/j.arcped.2013.11.014

[13] Garba, M., Kamaye, M., Alido, S., Zoubeirou, H., Oumarou, Z. and Amadou, A. (2017) Les déterminants de la mortalité néonatale précoce à la maternité Issaka-Gazobi de Niamey. Journal de Pediatrie et de Puériculture, 30, 156-161. https://doi.org/10.1016/j.jpp.2017.01.005

[14] Manzar, N., Manzar, B., Yaqoob, A., Ahmed, M. and Kumar, J. (2012) The Study of Etiological and Demographic Characteristics of Neonatal Mortality and Morbidity-A Consecutive Case Series Study from Pakistan. BMC Pediatrics, 12, Article No. 131. https://doi.org/10.1186/1471-2431-12-131

[15] Baker, L.C., Afendulis, C.C., Chandra, A., McConville, S., Phibbs, C.S. and Fuentes-Afflick, E. (2007) Differences in Neonatal Mortality among Whites and Asian-American Subgroups: Evidence from California. Archives of Pediatrics and Adolescent Medicine, 161, 69-76. https://doi.org/10.1001/archpedi.161.1.69

[16] Kramer, M.S., Liu, S., Luo, Z., Yuan, H., Platt, R.W. and Joseph, K.S. (2002) Analyse de la mortalité périnatale et de ses composantes: Il est temps de changer? American Journal of Epidemiology, 156, 493-497.

[17] WHO Regional Office for Europe (2005) Base de données européenne sur la santé pour tous. Organisation mondiale de la santé, Bureau Régional Européen, Copenhague. http://www.euro.who.int/InformationSources/Data/20010827_1

[18] Nguyen Ngoc, N.T., Merialdi, M., Abdel-Aleem, H., Carroli, G., Purwar, M., Zavaleta, N., Campódonico, L., Ali, M., Hofmeyr, G.J., Mathai, M., Lincetto, O. and Villar, J. (2006) Causes of Stillbirths and Early Neonatal Deaths: Data from 7993 Pregnancies in Six Developing Countries. Bulletin of the World Health Organization, 84, 699-705. https://doi.org/10.2471/BLT.05.027300 
[19] Ministère de la Santé et de la Population (2006) Plan National de Développement Sanitaire 2006-2015. 87 p.

[20] Chelo, D., Monebenimp, F., Romyale, F., Npanguepko, T. and Tietche, F. (2012) Mortalité néonatale précoce et ses déterminants dans une maternité de niveau I à Yaoundé, Cameroun. Pan African Medical Journal, 13, Article No. 67.

[21] Akinyemi, J.O., Bamgboye, E.A. and Ayeni, O. (2015) Trends in Neonatal Mortality in Nigeria and Effects of Bio-Demographic and Maternal Characteristics. BMC Pediatrics, 15, Article No. 36. https://doi.org/10.1186/s12887-015-0349-0

[22] Blondel, B., Eb, M., Matet, N., Bréart, G. and Jougla, E. (2005) La mortalité Néonatale en France: Bilan et apport du certificat de décès néonatal. Archives de Pédiatrie, 12, 1448-1455. https://doi.org/10.1016/j.arcped.2005.05.009

[23] OMS, Bureau régional de l'Afrique (2014) Plan Stratégique Régional pour la Vaccination 2014-2020.

[24] Adetola, A.O., Tongo, O.O., Orimadegun, A.E. and Osinusi, K. (2011) Neonatal Mortality in an Urban Population in Ibadan Nigeria. Pediatrics \& Neonatology, 52, 243-250. https://doi.org/10.1016/j.pedneo.2011.06.001

[25] Mengesha, H.G., Wuneh, A.D., Lerebo, W.T. and Tekle, T.H. (2016) Survival of Neonates and Predictors of Their Mortality in Tigray Region, Northern Ethiopia: Prospective Cohort Study. BMC Pregnancy and Childbirth, 16, Article No. 202. https://doi.org/10.1186/s12884-016-0994-9

[26] Mekonnen, Y., Tensou, B., Telake, D.S., Degefie, T. and Bekele, A. (2013) Neonatal Mortality in Ethiopia: Trends and Determinants. BMC Public Health, 13, Article No. 483. https://doi.org/10.1186/1471-2458-13-483

[27] Sidibé, T., Sangho, H., Doumbia, S., Sylla, M., Keita, M., Keita, H.D., et al. (2006) Mortalité néonatale dans le district sanitaire de Kolokani (Mali). Journal de Pédiatrie et de Puériculture, 19, 272-276. https://doi.org/10.1016/j.jpp.2006.08.004

[28] Lukonga, E. and Michelo, C. (2015) Factors Associated with Neonatal Mortality in the General Population: Evidence from the 2007 Zambia Demographic and Health Survey (ZDHS); A Cross Sectional Study. Pan African Medical Journal, 20, Article No. 64.

[29] Lassi, Z.S., Middleton, P.F., Bhutta, Z.A. and Crowther, C. (2016) Strategies for Improving Health Care Seeking for Maternal and Newborn Illnesses in Low and Middle-Income Countries: A Systematic Review and Meta-Analysis. Global Health Action, 9, Article ID: 31408. https://doi.org/10.3402/gha.v9.31408

[30] Labie, D. (2005) Le scandale des 4 millions de morts néonatales chaque année: Bilan et actions possibles. Médecine/Sciences, 21, 768-771.

[31] Muluken, G., Mitike, M. and Wubegzier, M. (2014) Trends and Risk Factors for Neonatal Mortality in Butajira District, South Central Ethiopia, (1987-2008): A Prospective Cohort Study. BMC Pregnancy Childbirth, 14, Article No. 64. https://doi.org/10.1186/1471-2393-14-64

[32] Singh, K., Brodish, P. and Suchindran, C. (2014) A Regional Multilevel Analysis: Can Skilled Birth Attendants Uniformly Decrease Neonatal Mortality. Maternal and Child Health Journal, 18, 242-249.

[33] Lee, H.Y., Do, D.V., Choi, S., Trinh, O.H. and To, K.G. (2016) Trends and Determinants of Infant and Under-Five Childhood Mortality in Vietnam, 1986-2011. Global Health Action, 9, Article ID: 29312. https://doi.org/10.3402/gha.v9.29312

[34] Musafili, A., Essén, B., Baribwira, C., Binagwaho, A., Persson, L.A. and Selling, K.E. 
(2015) Trends and Social Differentials in Child Mortality in Rwanda 1990-2010: Results from Three Demographic and Health Surveys. Journal of Epidemiology and Community Health, 69, 834-840. https://doi.org/10.1136/jech-2014-204657

[35] Kimani-Murage, E.W., Fotso, J.C., Egondi, T., Abuya, B., Elungata, P., Ziraba, A.K., et al. (2014) Trends in Childhood Mortality in Kenya: The Pour Citer Urban Advantage Has Seemingly Been Wiped out. Health \& Place, 29, 95-103. https://doi.org/10.1016/j.healthplace.2014.06.003

[36] Sanogo, C.T. (2008) Etude épidémio-clinique d l'accouchement prématuré au centre de santé de référence de la commune $\mathrm{V}$ de 2002 à 2003 à propos de 238 cas. Université de Bamako, Bamako, 19 p.

[37] Agbere, A.D., Bayilabou, K., Tatagan, K., Assimadi, K. and Kessie, K. (1998) Mortalité néonatale précoce dans le service de pédiatrie du CHR de Kara. Publications Médicales Africaines, 126, 9-14.

[38] Ayivi, B., Alihonou, E., Dan, V. and Koumakpai, S. (1994) Médecine néonatale au Bénin: Etat actuel et perspectives d'avenir. Médecine d' Afrique Noire, 41, 491-495.

[39] Alihonou, E., Dan, V., Ayivi, B., Sossou, E.C., Gandaho, T. and Koumakpai, S. (1991) Mortalité néonatale au centre national hospitalier et universitaire de Cotonou: Incidence, causes et moyens de lutte. Médecine d’ Afrique Noire, 38, 746-751.

[40] Azria, E. (2015) Inégalités sociales en santé périnatale. Archives de Pédiatrie, 22, 1078-1085. https://doi.org/10.1016/j.arcped.2015.07.006

[41] Villar, J. and Belizan, J.M. (1982) The Relative Contribution of Prematurity and Fetal Growth Retardation to Low Birth Weight in Developing and Developed Societies. American Journal of Obstetrics \& Gynecology, 143, 793-798. https://doi.org/10.1016/0002-9378(82)90012-6

[42] Bégué, P. and Capochichi, D. (1979) Les nouveau-nés de petits poids de naissance au Togo. Classification en fonction de l'âge gestationnel à partir de 888 cas. Annals of Pediatrics, 26, 639-645.

[43] Diallo, A.H., Meda, N., Oue'draogo, W.T., Cousens, S. and Tylleskar, T. (2011) A Prospective Study on Neonatal Mortality and Its Predictors in a Rural Area in Burkina Faso: Can MDG-4 Be Met by 2015? Journal of Perinatology, 31, 656-663. https://doi.org/10.1038/jp.2011.6

[44] Shrimpton, R. (2003) Preventing Low Birthweight and Reduction of Child Mortality. Transactions of the Royal Society of Tropical Medicine and Hygiene, 97, 39-42.

[45] Shankaran, S., Fanaroff, A.A., Wright, L.L. and Stevenson, D.K. (2002) Risk Factors for Early Death among Extremely Low-Birth-Weight Infants. American Journal of Obstetrics \& Gynecology, 186, 796-802. https://doi.org/10.1067/mob.2002.121652

[46] Cisse, C.T., Yacoubou, Y., Ndiaye, O., Diop-Mbengue, R. and Moreau, J.C. (2006) Évolution de la mortalité néonatale précoce entre 1994 et 2003 au CHU de Dakar. Journal de Gynécologie Obstétrique et Biologique de la Reproduction, 35, 46-52. https://doi.org/10.1016/S0368-2315(06)76371-2

[47] Kabore, P., Potvliege, C., Sanou, H., Bawhere, P. and Dramaix, M. (2004) Croissance pondérale et survie des enfants de petit poids de naissance nés à terme en milieu rural africain (Burkina Faso). Archives de Pédiatrie, 11, 807-814. https://doi.org/10.1016/j.arcped.2004.03.034

[48] Jehan, I., Harris, H., Salat, S., et al. (2009) Neonatal Mortality, Risk Factors and Causes: A Prospective Population-Based Cohort Study in urban Pakistan. Bulletin of the World Health Organization, 87, 130-138.

https://doi.org/10.2471/BLT.08.050963

[49] Titaley, C.R., Dibley, M.J. and Roberts, C.L. (2012) Type of Delivery Attendant, 
Place of Delivery and Risk of Early Neonatal Mortality: Analyses of the 1994-2007 Indonesia Demographic and Health Surveys. Health Policy and Planning, 27, 405-416.

[50] Beck, L. (2009) La santé des nouveau-nés au Rwanda. Évolution des facteurs associés aux tendances de la mortalité néonatale. Santé Publique, 2, 159-172.

[51] Ratovoarisoa, N.M., Randriamanantena, S.N.C., Raveloharimino, N.H. and Rabesandratana, H.N. (2020) Morbidité néonatale sur 10 ans dans un complexe mère enfant de Madagascar. Revue Malgache de Pédiatrie, 3, 70-77.

[52] Ben Hamida Nouaili, E., Chaouachi, S., Ben Said, A. and Marrakchi, Z. (2010) Déterminants de la mortalité néonatale, dans une population tunisienne. La Tunisie Médicale, 88, 42-45

[53] Lawn, J.E., Blencowe, H., Oza, S., You, D., Lee, A.C.C., Waiswa, P., Lalli, M., Bhutta, Z., Barros, A.J.D., Christian, P., Mathers, C. and Cousens, S.N. (2014) Every Newborn: Progress, Priorities, and Potential beyond Survival. The Lancet, 384, 189-205. https://doi.org/10.1016/S0140-6736(14)60496-7

[54] Yenan, J.P., Plo, K.J. and Asse, K.V. (2014) Morbidité et mortalité néonatales au service de pédiatrie du CHU de Bouaké. RAMUR, 18, 2-12.

[55] Aiken, L., Clarke, S., Sloane, D., et al. (2012) Patient Safety, Satisfaction, and Quality of Hospital Care: Cross Sectional Surveys of Nurses and Patients in 12 Countries in Europe and the United States. British Medical Journal, 344, e1717. https://doi.org/10.1136/bmj.e1717

[56] Code la santé publique. Article D6124-61. https://www.legifrance.gouv.fr/

[57] Vrijheid, M., Dolk, H., Stone, D., et al. (2000) Socioeconomic Inequalities in Risk of Congenital Anomaly. Archives of Disease in Childhood, 82, 349-352.

https://doi.org/10.1136/adc.82.5.349 